\section{E-LOGOS}

ELECTRONIC JOURNAL FOR PHILOSOPHY ISSN 1211-0442

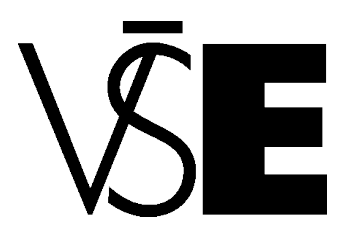

University of Economics

Prague

\title{
Definování areté v Platónově dialogu
}

\section{Menón}

František Weis

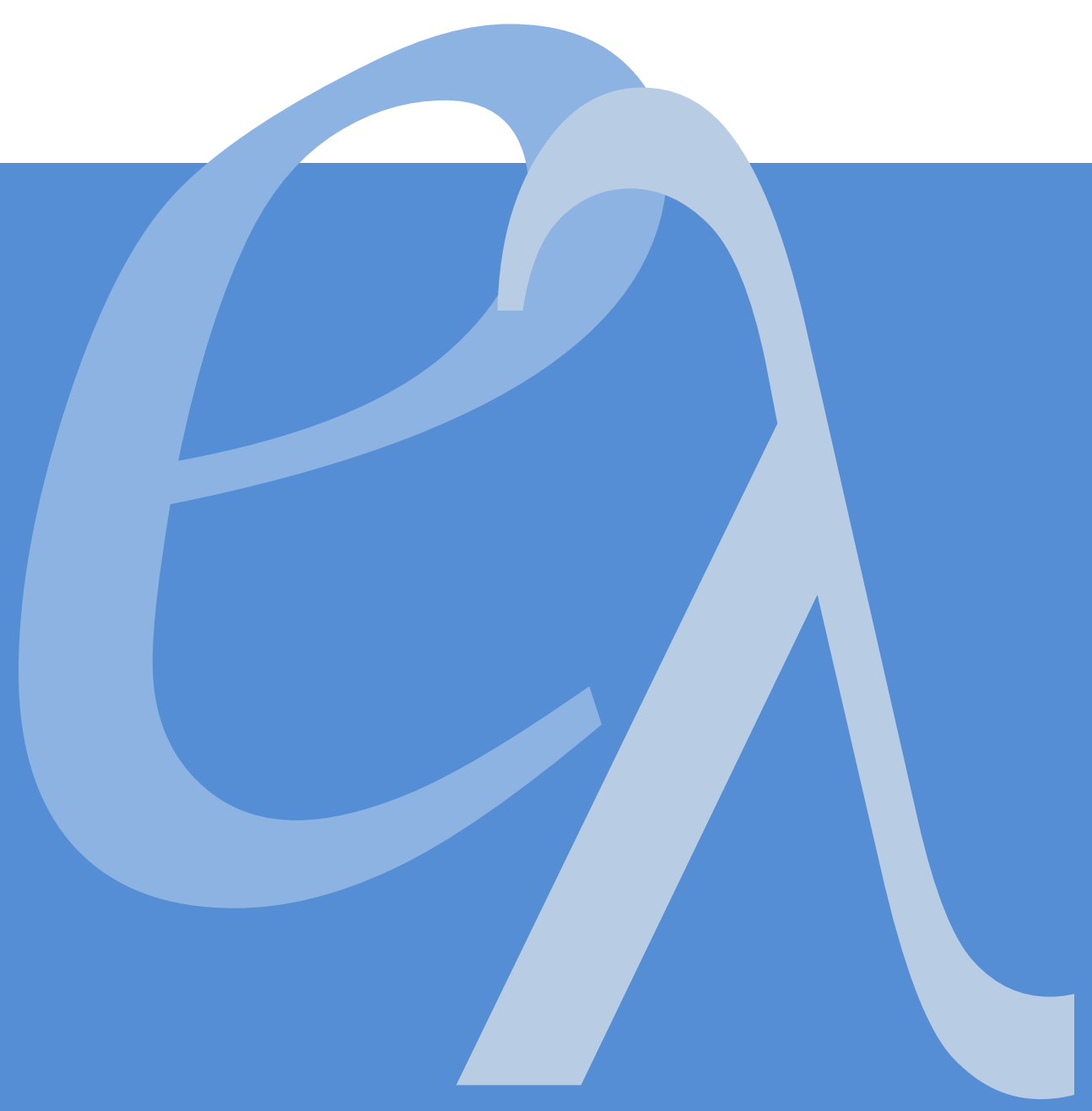




\begin{abstract}
The presented article is concerned with an analysis of the first part of Plato's dialogue Meno. It shows what lies behind the scenes of the literally work in terms of the clash between external greatness of dying Greek tradition and internal greatness of the person acquainted with living experience of (his own) sense of human life. All three attempts of define what arete is, unmask with the thoroughgoing research mere rhetorical duel between Meno and Socrates as the struggle mentioned above.
\end{abstract}

Keywords: arete, tradition and moral individuality.

\begin{abstract}
Abstrakt
Předložená práce je textově filosofickou analýzou první části Platónova dialogu Menón, přičemž se snaží předvést, jak v konkrétním literárním díle Platónově je obsažen střet mezi silou již skomírajícího světa tradice (s jejími hodnotami lidského života), a silou jedince, který hodnoty lidského života sám pro sebe vydobyl v kritické diskusi s tradicí. Všechny tři pokusy definovat co je vlastně areté, odhalují při pečlivém rozboru pouhé rétorické střetnutí Menóna se Sókratem jako příklad střetu dvou odlišných paradigmat a sil, uvedených výše.
\end{abstract}

Klíčová slova: areté, tradice a morální individualita. 


\section{ÚVOD}

Přijmeme-li rozdělení dialogu na část elenchickou (do $80 \mathrm{~b}-\mathrm{d}$ ), a konstruktivně dialektickou (od 80e; v 80b-d je přechod mezi oběma částmi) ${ }^{1}$, je tato práce věnována téměř bez výhrad části první. Soustředí se na popis argumentace obou stran dialogu (Sókrata a Menóna) při pokusech o definování areté, a s využitím sekundární literatury se pokusí při zohlednění širších významových souvislostí postup definování hlouběji interpretovat.

\section{KULTURNÍ A HISTORICKÉ PŘEDPOKLADY}

Jedno z hlavních témat Menóna ${ }^{2}$, areté, není něčím, co by se jako filosofické téma vynořilo teprves př́chodem Sókratovým (či Platónovým). Nese si svou minulost; tam, kde je o areté řeč, je vždy již odkaz na doby dřivějšíi, ozývají se $\mathrm{v}$ pozadí verše Homérovy, ožívá agonická tradice s velkými vojenskými nárazy at’ v rámci antického řeckého světa samého (mezi jednotlivými mocenskými centry, poleis), at' mezi tímto antickým světem řeckým a světem odlišným (zejména Persie). Polemos, boj, a ten kdo v něm prokáže svou výjimečnost (která není nutně hrubou fyzickou silou či bojovou zručností, ale též zchytralostí, jak ukazuje př́klad Odysseův), jsou tu hlavními osami, v nichž se rýsuje a ukazuje vlastní povaha areté, a kontext srážek a střetů („,polemiky“ v širokém slova smyslu) přetrvává pro téma areté i v dobách neválečných, jelikož se již stal součástí tradice.

Je ovšem tradice uvědomělá, a pak také tradice neuvědomělá, a Platónův dialog Menón je kromě jiného brilantní ukázkou nárazu takového stanoviska životního, která tradici s jejími hodnotami bere za samozřejmou (cítí zároveň již její slabost), a jako samozřejmou ji používá v rámci své praxis, ${ }^{3}$ se stanoviskem jiným, které tradici bere vážněji než jako samozřejmost. Se stanoviskem, které se ptá po hlubších motivech tradice, a hledá její další zdůvodnění než pouze ono historické "tak se vždy dělo“. Otázka po areté tak pro jednu stranu - tu představuje postava Menóna - vlastně vůbec není otázkou, ale spíše záminkou. Záminkou k předvedení své schopnosti řečnictví. V tomto ohledu je Menón jako postava jednoduchá4; složitost a náročnost přichází teprve s postavou Sókratovou. Již jen otázka, zda v oné kontrapozici k Menónovi jde

${ }^{1}$ Helena Kurzová, K interpretaci Platónova dialogu Menón, in: sborník Platónův dialog Menón, ed. Aleš Havlíček, 2000, str. 40.

${ }^{2}$ Těch témat je - oproti většině ostatních platónských dialogů - více: patř̌i mezi ně zejména areté, definování, zkoumání, učitelnost areté, anamnésis, vědění... „Menón má velmi pestrý program námětový“, ř́ká Patočka ve svých přednáškách o Platónovi z let 1947-1948; viz Patočka (1992), Platón, str. 195.

3 Praxis, jednání, která jsou něčím novým, „novou paideia“, novou životní výchovou, ř́íká Patočka v popisu společenské vrstvy sofistů.

${ }^{4}$ Menónova postava (ve svém názoru na areté) prostě jen předvádí to, co obsahovala "tradovaná předfilosofická občanská etika, vykrystalizovaná hlavně v oslavných, zejména pohřebních řečech", viz Kurzová (2000) str. 41. 
o Sókrata či Platóna či o oba, činí z otázky po areté pro současného interpreta potíž Klade totiž před něj pochybnost, zda se vposled u této druhé strany jedná o motiv antropologicko-morální, či o názvuk něčeho jiného, totiž o metafysický koncept, o místo člověka $v$ nějakém spekulativním rámci. To anebo životní styl? Zůstaňme pro začátek u obrazu doby, jímž je historicky relevantní debata mezi zastánci fysis a zastánci nomos; a vstupme zároveň do proudu zápasu mezi sofistickou „výukou areté" a sókratovským tázáním.

Menón jako postava stejnojmenného dialogu je v uvedeném literárním kontextu zhmotněním tradičního pohledu na areté: jde především o mužskou aktivní schopnost osvědčit $\mathrm{v}$ boji odvahu. Další schopnosti ceněné $\mathrm{v}$ tomto tradičním pohledu moudrost, spravedlnost, umírněnost a zbožnost - jsou spojeny se životem společnosti jako celku (proto bývají $\mathrm{v}$ akademických debatách nazývány tyto aretai kooperativními), a jsou schopnostmi druhého řádu. Jiný obecně společensky zastávaný názor, který Menón ilustruje, je představa o výlučnosti zdrojů aretai: jako lze excelentní bojovníky spočítat na prstech ruky (ač třeba všichni bojují dobře, jen málokteří bojují výjimečně dobře), jako je pravděpodobnější, že některou z aretai získá spíše muž než žena, dítě či stařec, tak je pravděpodobné, že areté získá jen někdo (otázka úplného výčtu všech aretai, či výčtu jejich společného - esenciálního - rysu, není v tradičním pohledu vůbec postavena; postačuje plně výčet dle běžného úzu). Při snaze získat některou areté musí člověk prokázat dostatečnou dravost; areté je totiž jako kořist, již třeba ulovit, poprat se o ni s jinými, a prokázat větší sílu než ostatní. Takovou areté je pro Menóna bezesporu také schopnost těch nejznamenitějších sofistů ovládnout řeč jako nástroj, s jehož pomocí pak ovládají ostatní, či pomohou (za úplatu) někomu dalšímu ostatní ovládat či ostatním vládnout. Někteří interpreti chápou Sókrata rovněž jako svého druhu sofistu (bez nároku na honorář, ale se silnou zálibou ve vyvracení názorů druhých), pro jiné je jeho postava otevřením nové dimenze střetu názorů - dimenze morální. Ačkoli se kloním ke skupině druhé, i bez tohoto rozlišení zůstává významnou ta otázka, jestli vynikání lze myslet jen kompetitivně vůči jiným lidem, anebo i vůči sobě samému - jaký ohromný posun to obnáší v kontextu posouzení! A není snaha ovládnout sebe sama úsilím morálním?

\footnotetext{
${ }^{5}$ Patočka upozorňuje ve svých přednáškách o Sókratovi, nebo v Negationím platonismu na posun od původně sókratovského antropologického motivu nedisponovatelné morální sféry, a Platónovy verze přetvoření uvedeného motivu do kosmologické podoby Ideje (a metafysiky idejí oproti smyslovému světu). Jiní interpreti - Bedu-Addo (1984) - v Menónu vidí unikátní dialog v tom ohledu, že se v něm Platón poprvé odpoutává od svého učitele a právě z témat morálních přechází $\mathrm{k}$ tématům "čisté filosofie“, ve snaze koncipovat koherentní pojetí poznání (pro tyto interprety nejde v dialogu v posledku ani o areté, ani o anamnésis, rozpomínání, ale o povahu zkoumání samotného: sám proces zkoumání se stává předmětem zkoumání). Podobně pro Irwina je Menón vedle Prótagory a Gorgii dialogem, který může být věrohodně chápán jako známka přechodu od expozice sókratovského stanoviska k úvodu do odlišné pozice Platónovy. (Terence Irwin, The Development of Ethics, Volume I, 2007, str. 69; podobně ale i Patočka, Platón, str. 195 - „první rozvrh odpovědi nikoli praktické, ale filosofické").
} 


\section{PRVNÍ DEFINICE aneb „potpourri předností“ ${ }^{6}$ (71e-73c)}

Jedna z metod úderů a tlaků na nervová centra lidského těla ve spojení s páčením kloubů a využíváním pohybu útočníka, charakteristická pro 9. století n.l. v Japonsku, se později stala známou pod názvem aikidó. A s nadsázkou řečeno aikidó je přesně to, co se technicky vzato v Menónu děje hned po příkrém vpádu otázky po učitelnosti areté (70a). Za co jiného považovat Sókratovu odpověd' než za duševní aikidó? Menóna, který je domněle pevně usazen $\mathrm{v}$ sedle namemorovaných znalostí a osvojených slovních triků, nejen nevyvrací (stylem „ty, Menóne, si díky Gorgiovi myslíš, že znáš areté, ale já ti teprve ukážu, co to areté je“), ale právě naopak, energii úvodního podcenění znásobí (stylem „já se s tebou Menóne, s Gorgiou, ba žádným z Thesálie, nemohu rovnat - nejen nevím lépe, co je areté, ale vlastně ji neznám vůbec; dokonce jsem ani nepotkal tady v Athénách nikoho, kdo by mi to řekl...“).

Rozložení sil na bitevním poli dialogu se rázem mění: vyvstává otázka po ti esti, co je sama areté? Jak lze popsat zpơsob jejího nabývání, když nevíme, co přesně je? Pro upřesnění podává Sókratés př́íklad, jemuž nechybí ironický šleh po Menónově charakteru, po předmětu jeho pýchy: kdo vůbec nezná Menóna, jak by mohl vědět o jeho kráse, bohatství a urozenosti? Avšak když ne Menón sám, tedy alespoň interpret se musí pozastavit nad takto podanou ilustrací v 71b. Proč je volen zcela odlišný řád příkladů? Co znamená tahle zamlčená nesouměřitelnost areté a Menóna? O Menónovi (pravděpodobně) není obecná znalost, naopak $\mathrm{z}$ obecné znalosti areté téměř všichni vychází. Menón nemá jako jméno jazykově ustálený význam7, avšak areté jej má, a ve stejném smyslu je Sókratovo stanovisko v pozdější replice vůči Anytovi (93b nn.) podobně zavádějící: podle Anyta se slušní lidé (slušní Atéňané) stali slušnými tím, že se to naučili od svých předchůdců - tj. slušnost, ač nereflektovaně, je ztotožněna s kulturní tradicí. Co hledá Sókratés (místy poněkud uměle a násilně), je nehistorický fakt (a rozumějme tomu spíše tak, že jde o odkaz na sféru bohů, o hledání trvalosti $\mathrm{v}$ mimolidské sféře). Sókratés cíleně zpředmětňuje něco, co se samo zpředmětnění ze své povahy brání - je zdatnost věc, kterou lze získat a př́ípadně odevzdat dál (učením)? Na otázku, zda je Menón něco tak obecného jako areté lze tedy možná odpovědět: není, ale třeba právě na tom, že tuto rozdílnost Menón vůbec nezachytí, se ukazuje, že „znát" pro něj znamená vždycky znát něco konkrétního (i namemorované empedokleovské nauky jsou $\mathrm{v}$ tomto smyslu něco konkrétního); bezprostřednost je pro něj vším. A jemu samému jde o osobní, co nejskvělejší vlastní bezprostřednost; tento charakterový rys má nejspíš Sókratés na zřeteli, když nejen dá na roveň př́klad konkrétní věci oproti něčemu obecnému (Menón oproti aretê), ale ještě přitom

6 Půvabný pojem „potpourri of virtues“ užila k popisu 1.definice areté Roslyn Weiss (2001), Virtue in the Cave, Moral Inquiry in Plato's Meno. Oxford University Press 2001, str. 25.

7 Ponechejme stranou možnost, že v samotném dialogu - podobně jako v jiných dialozích může i jméno některých hlavních postav skrývat význam spojený s etymologickým původem jména (podobně jako v Obraně Sókrata je to žalobce Melétus - ironicky od melété = starat se). 
konkrétní věc popíše slovy „krásný nebo bohatý nebo urozený“ (71b). Pro další průběh dialogu je však i v tomto bodě vhodné upozornit ještě na jiný zamlčený aspekt: na rozdílné způsoby, které může znamenat ono „znát“ v př́kladu „znát Menóna“: 1.) povrchně; což stačí k popisu typických vnějších znaků, charakteristik, 2.) hlouběji; například tím, že s ním/vedle něj člověk nějakou dobu žije; což je nutné k popisu charakteru. Jak "zná" areté Menón a hlavně - jak Sókratés? To je jedna ze strukturních vrstev, kterou je protkán celý dialog. Leč nepředbíhejme. Menón žádný problém v př́ikladu nevidí, a podává první definici:

Však není těžké, Sókrate, to povědět. ... je nasnadě, že to je areté muže, býti schopen spravovat věci obce a při té činnosti dělat přátelům dobře, nepřátelům zle, a sám se mít na pozoru, aby se mu nic takového nestalo. ... areté ženy není nesnadné vyložit ... má dobře spravovat dům, opatrujíc věci domácnosti a jsouc poslušna svého muže. A jiná je areté dítěte, děvčete i hocha, a jiná staršího muže, bud' svobodného nebo otroka. A je přemnoho jiných aretai, takže nepưsobí nesnáze říci o areté, co jest; nebot v každém oboru činnosti a v každém věku i ke každému úkonu náleží každému z nás areté" (71e72a)

Jak vidno, Menón rád vysvětlí Sókratovi, co je areté: je to tohle, tohle a tohle, a vlastně každá činnost má své „výtečníky“ , což tohle, Sókrate, nechápeš? Jenže Sókratés chápe až př́iliš dobře, jak těžká věc je areté, a že formální definice výčtem se míjí s jejím vlastním smyslem. Aby kontrastoval životní zaměření Sókratovo, hodnotí Patočka Menónem zastávaný názor takto: „Vulgární názor ovšem, který nic neví o pravém smyslu areté, dívá se na věc trochu jinak. I běžný život hodnotí a rozlišuje, ví dobře o rozdílu mezi tím, co v životě je běžné, a tím, co je nesnadné a mimořádné. Ale běžný život se právě spokojuje diskontinuitou a klade vedle sebe statečné a nestatečné lidi a chvíle, právě tak zbožné a bezbožné, atd., jako by šlo o bílé a červené růže, o skutečnosti, jež se konstatují. Pro běžný názor je tedy příznačná rozmanitost a diskontinuita ,dokonalostí, , aretai; on zná toliko různé formy, nikoli to, proč ty to různé formy jsou formami téhož. “8

8 "A od toho se nijak neuchyluje odborník, který tvrdí, že areté je možno učit, aniž se stará dále o to, co areté vlastně je“, Patočka: Sókratés, str.126. Mohli bychom věc formulovat i tak, že zatímco Menón zůstává vězet ve vrstvě vulgárních fenoménů, prokazuje Sókratés schopnost procházet plynule skrze tuto vrstvu $\mathrm{k}$ fenoménům hlubším (ne apriori hlubším morálně, ale významově), a zároveň si ještě zůstává vědom toho, že onen průchod sám není nic samožrejmého, že je vydobýván vlastní aktivitou elenchu, jak vidno $\mathrm{v}$ opozici $\mathrm{k}$ později uvedené eristické myšlence $(80 \mathrm{~d})$, která jen alibisticky ospravedlňuje lenost a intelektuální neochotu. Elenchos je v tomto ohledu tím „vázáním“, o němž je řeč v 98a, a totéž "vázání" a jeho průběžné výsledky jsou onou "zkušeností", která umožňuje kvalifikovanou mluvu (nikoliv Anytovo „věštectvi“) - viz 92c; podobně 89c: „nestačí jenom, aby se bylo prve zdálo ... nýbrž musí se to zdát i nyní i potom“; téměř jako by tu byla řeč o eidetickém názoru fenomenologie, který není žádným zřením od těla osvobozené duše v říši idejí (ale možná tady nejsem práv Platóna), a říše idejí je sice interpretovatelná metafysicky jako jiná ř́ře oproti světu aisthésis, ale též ji lze chápat ve smyslu „negativního platonismu“ Patočkova, kdy jde o to popsat 
A pak je tu ještě něco: Menónova osobní povaha. Zastavíme-li se u ní, zarazí nás ta zvláštní věc, že (morální) povaha (vlastně obou) postav dialogu je tak podstatná pro samotnou argumentaci. Na pozadí otázky ti esti? stojí otázka „Jak vidíš ty sám svůj život a jeho cíl či cíle, ke kterým ho vedeš?" 9 Různé př́iklady areté postrádají jednotící pohled, např́iklad přes ta heautou prattein (,konat to své nejvlastnějšíi”); to je ale záležitostí Platónovy Ústavy, nikoliv dialogu Menón. Nakolik je zásada ta heautou prattein blízká Menónovi jako postavě? Téměř by se chtělo říci, že velmi, jenže zcela odlišným způsobem: namísto „konat to své nejvlastnějšíi” znamená spíše cynické „hledět si svého“, přričemž např́iklad popperovská (mis)interpretace Platónovy Ústavy ukazuje jak dvojsečné je určení měřítka, kterým se následně posoudí význam onoho heautou. Pravda vítězí; pravda vítězi; specifické "ta heautou prattein" nad branou osvětimského lágru klade před jejího čtenáře otázku: „Čí práce?" a "Čí svoboda?", přičemž zároveň neponechává otevřeným, kdo na ni jediný může odpovídat. Je Sókratovým "objevem“, ovocem jeho boje s tradicí, že na otázku po ta heatou prattein může odpovídat kdokoli, dokonce i tam, kde mu někdo jiný či tradice vkládají odpověd’ do úst, předem připravenou a hotovou. S Popperem bychom mohli syrově říci: Menónova areté je dostat se např́iklad na místo obergruppenführera, a oscarový Předčitač ${ }^{10} \mathrm{v}$ roli Kate Winslet ukazuje, jak takto pojatá areté může prakticky vypadat: jde o výkon odpovědnosti za vězně, kteří mohou uhořet, ale nesmí se ztratit. Ale odpovědnost není antické téma, ba ani v rámci antických tragiků; odpovědnost je Sókratův dar, Platónem zmetafysičtěný, a teprve $v$ dalším průběhu dějin (i díky konfrontaci s židovsko-křest'anským náboženstvím) v Evropě zdomácnělý, byt' zároveň za tu cenu, že ono komu se odpovídá, je přesunuto z vlastní duše na boha, a vlastní smysl chórismu zapomenut. ${ }^{11}$ Ale zpět k dialogu.

oblast, o níž se dnes běžně mluví jako o oblasti kulturní - nurture oproti nature, a která je spíše oblastí nadindividuálně duševní, má-li smysl to takhle formulovat, a nemyslím tím ani jungovské kolektivní nevědomí, ale oblast, která - třeba jako vztah - vyžaduje, aby do ní někdo energii dával, ji pěstoval, protože je pouhou (lepší) možností člověka, nikoli nutností či povinností.

${ }_{9}^{9}$ Barvitě líčí Menónův charakter Xenofón - vezměme tuto možná literární nadsázku jen trochu vážně, a hned nám bude zřejmější, že povaha toho, kdo hovoří o areté, je mnohdy pro smysl definice určující: „O Thessalovi Menónovi bylo známo, že strašně touží zbohatnout a že usiluje o velení, aby mohl nabrat víc majetku, a o pocty, aby jich získal ještě víc. Proto chtěl být přítelem nejmocnějších, aby unikl trestu, když způsobí bezpráví. Za nejkratší cestu k dosažení toho, po čem toužil, považoval křivopřísežnictví, lži a podvody; upřímnost a pravdu měl za hloupost. Bylo jasné, že nemá rád nikoho, a proti tomu, kdo říkal, že je jeho př́telem, určitě chystal nějaký úklad. Žádnému nepříteli se nevysmíval, ale s lidmi ze svého okolí mluvil vždy tak, jako by si z nich tropil šašky. Proti majetku svých neprátel úklady nestrojil, nebot' měl za to, že je obtížné brát něco lidem, kteří se mají na pozoru. Pokud jde o majetek přátel, myslel si, že jen on ví, jak velice snadné je brát, co se nehlídá. Lidí, o nichž zjistil, že jsou křivopř́sežníci a darebáci, se bál, jako by byli dobře ozbrojeni, kdežto s lidmi počestnými a pravdomluvnými se pokoušel jednat jako se zbabělci. Jako se někdo honosí zbožností, tak byl Menón pyšný na to, že umí podvádět, vymýšlet lži a vysmívat se přátelům. Kdo nebyl bezohledný, toho považoval vždycky za hlupáka." Xenofón, Anabaze, Odeon 1974, str. 82.

${ }^{10}$ The Reader (Předčítač), režie Stephen Daldry, USA/Německo 2008.

${ }^{11}$ Blíže k tomuto filosoficko-historickému tématu např. Patočka, Věčnost a dějinnost, ale i Kacírské eseje o filosofii dějin. Na obranu Menóna budiž řečeno, že „řecká etymologie <areté> ... nejspíš poukazuje na její škálový původ“, viz Josef Moural, Několik poznámek k Platónovu dialogu Menón, in: Aleš Havlíček 
Ze snůšky různých př́ikladů areté si Sókratés vybírá areté ženy - „dobře spravovat dům“ (71e), a ono „dobře spravovat“ rozššří i na mužskou areté, přičemž Menón souhlasí, že prohlásil za areté muže „dobře spravovat obec“, což není zcela v souladu s jeho skutečným dřivějším vyjádřením („býti schopen spravovat věci obce a při té činnosti dělat přátelům dobře, nepřátelům zle, a sám se mít na pozoru, aby se mu nic takového nestalo“ ,71e). Zároveň dojde ještě k jednomu posunu vedle rozšíření „dobře spravovat" z femininní oblasti do maskulinní: ze sousloví „spravovat dobře“ je to právě ono „dobře“, v němž leží těžiště Sókratova zájmu. Není pochyb, že těžiště zájmu jeho společníka v rozmluvě je naopak ono „spravovat“, jak se ukáže i v jeho druhém pokusu o definici (,já nazývám areté to, toužit po krásných věcech a býti schopen si je opatrovat", $77 b)$, během kterého se znovu plně projeví Menónův zvyk či charakterový rys instrumentalizovat jak své vlastní cíle, tak prostředky, kterými jich doufá dosáhnout. Rys instrumentalizace však Sókratés opouští záhy: od „dobře spravovat“ se v 73b-c přesune $\mathrm{k}$, jestliže mají být dobři" , "Mohli by se ... stát dobrými?" a "Všichni lidé jsou dobří týmž způsobem; nebot' se stávají dobrými, když dosáhnou týchž vlastností". At' už je či není motivem takového přesunu snaha "přeladit" Menóna či přeladit řeč na nějaký jiný motiv, není výsledek valný. Menón dá opět přednost, patočkovsky řečeno, koncepci síly a ovládání síly díky jejímu poznání, jak je zcela nepokrytě vidět v novém pokusu o definici: areté je "schopnost vládnout nad lidmi“ (73c, vládnout = archein, srovnejme výskyt tohoto termínu v 86d, kde se Sókratés označuje za pána nad sebou, zatímco Menóna označuje za toho, kdo o sebevládu nestojí). Jde o další místo dialogu, v němž je jasně vidět střet dvou zcela odlišných koncepcí - vedle mít versus být je to právě vláda nad druhými versus sebevláda. Je rovněž zřejmé, že Menón si sebedisponovatelnost vůbec neklade jako problém, je si jist, že je svým pánem. Č́m si jist není, je způsob, jak se co nejlépe stát pánem nad druhými. Je nabíledni, že od Sókrata se to nenaučí, a je to právě odlišný záběr obou postav, co vede některé komentátory $\mathrm{k}$ formulaci, že obě koncepce $\mathrm{v}$ dialogu o sebe narážejí, aniž by došlo k nějakému ústupu ze stanoviska, natožpak k řešení. ${ }^{12}$ Povaha samotného dialogu, který není vyhraněným akademickým pojednáním, ale je zároveň i literárním dílem, umožňuje - $\mathrm{k}$ mé lítosti bez dalšího dokazování, což se ale do velké míry týká vposledku i Patočkovy kongeniální interpretace Sókrata - některým interpretům o Menónovi prohlásit, že „ve skutečnosti pro něj existuje jen jedna areté, a to je areté muže; po té touží, té chce dosáhnout, a nevěří př́liš, že by měla vůbec něco

(ed.), Platónưv dialog Menón, str.50. Mít Menónovi za zlé, že je ilustrací své doby, bylo by od nás přeci jen poněkud nepatřičné.

12 Tak uvažuje např. Dominic Scott: Plato's Meno, Cambridge University Press, 2006, pro něhož je dialog Platónovým dramatickým vyjádřením konfliktu různých životních zájmů, v jehož průběhu vyvstane ne jedno, ale mnoho témat: areté, zkoumání, epistémé apod. S tím nesouhlasí Gail Fineová $\mathrm{v}$ recenzi Scottovy knihy, která v proměně témat spatřuje milníky na cestě, kterou aktéři prochází - ta cesta je pro ni "harmonický celek", „žádná nerozhodnutost, ale přirozený postup vzájemně souvisejících myšlenek" (blîže viz Fine, G., Enquiry and Discovery. A Discussion of Dominic Scott, Plato's Meno, Oxford Studies in Ancient Philosophy XXXII, Summer 2007). 
společného s ženami či dětmi, starými lidmi natož otroky!“13 U zdraví tak je ještě schopen připustit, že se nějak týká všech výše uvedených skupin, ale u areté se mu „jaksi zdá ... že toto již není podobno těm ostatním př́ípadům” (73a). Sókratés podobně se to děje v Platónově Ústavě v tzv. femininní části (V. kniha, 451c: „výstup ženský" ${ }^{\prime \prime}$ - tvrdí, že areté je stejná pro všechny, demokratizuje ji14. Nejde mu (jenom či v první řadě) o logický obrat, ale o obrat morální (v širokém slova smyslu): kdokoliv může získat areté, kdokoliv se může stát dobrým. ${ }^{15}$ Zároveň je v tomto obratu zahrnuta změna perspektivy: areté byt' individuální, nějak souvisí s celkem - nejen duše, ale i společnosti. Není náhoda, když se Sókratés - v reakci na tradiční výčet nejběžnějších aretai - snaží Menónovi vysvětlit, že mu jde o obecnou definici areté, a odvolá se přitom na příklad se včelami, tj. bytostmi, které jsou typickým př́kladem kooperace jednotlivců $\mathrm{v}$ zájmu celku. $\mathrm{V}$ průběhu dialogu ještě několikrát o sebe narazí tato dvě pojetí areté (elitářské a kooperativní). Pak přijde první výslovná zmínka o eidos, jednotícím vidu, a Menón „nechápe ještě tu otázku tak, jak by chtěl“ (72d). A zatímco zdraví, velikost a síla jsou pro Menóna myslitelné jako „tentýž druhový vid“ , u areté „toto již není podobno těm ostatním případům“ (73a). Nyní je významné, že Sókratés vsune Menónovi do úst, že dříve areté popsal jako „dobře spravovat", a nepozorný či ne dost duševně bystrý Menón souhlasí. Co se přitom děje? Zaprvé, Menón při popisu areté muže vůbec nevolil slovo „dobře“ (to slovo bylo užito u areté ženy), důraz byl jen na "spravovat", tedy ovládat, mít ve své moci. To, že Sókratés rozlišuje moc, nadvládu dobrou od špatné, je příznačné pro chápání rozdílu obou postav. Předtím, než přijde Menónův druhý pokus říci, co je areté, odkryje Sókratés docela své karty, aniž by to bylo reflektováno: „Tedy všichni lidé jsou dobří týmž zpưsobem; nebot' se stávají dobrými, když dosáhnou týchž vlastností" (73c). Žel překlad neumožňuje vidět zřetelněji tu dvojí rovinu, dvojí smysl stejného slova "dobré", protože pro Menóna je dobrý ten, kdo vyniká nad ostatními, pro Sókrata ten, kdo ovládl sám sebe; pro jednoho je důležité co bylo vykonáno (významné činy), pro druhého jak bylo cokoliv (i bezvýznamného) vykonáno. Zřejmá odlišnost je i v tom, že ono jak, které je pro získání areté nezbytnou podmínkou, Sókratés vůbec nemá $\mathrm{v}$ úmyslu omezovat na nějakou specifickou skupinu (muži, ženy, ale již ne otroci, staří lidé či děti); naproti tomu Menónovo co je takříkajíc z principu elitářské, což potvrdí vzápětí přicházející druhý Menónův pokus o definici.

13 Weiss, R. (2001), Virtue in the Cave, str. 26.

14 Slovy téže interpretky, viz Weiss (2001), str. 26.

15 Používám toto zdvojené vyjádření záměrně, pro zdůraznění etymologické blízkosti areté k pojmu dobra (upozornění na dokonce tautologický charakter definice areté pomoc pojmu dobra viz Aleš Havlíček, Proč Platón rozlišuje mezi fronésis a epistémé?, ve sborníku Platónův dialog Menón, str. 34, poznámka 12). 


\section{DRUHÁ DEFINICE (73c-77b) - „spravovat dobře“ aneb hlavně spravovat nebo hlavně dobře?}

Areté je pojata v druhé definici jako „schopnost vládnouti nad lidmi“ (73c). Proto nemůže na Menónův druhý pokus následovat jiná reakce, než upozornění na to, že ke "schopnosti vládnout" je vhodné přidat slova „spravedlivě a ne nespravedlivě" (73d), a opět to Menónovo nepochopení - přidejme klidně spravedlnost, vždyt' to je jiným slovem vyjádřeno totéž: areté. ${ }^{16}$ Metoda idealizace Menónovi stále uniká, „ještě nemohu, Sókrate, jak ty hledáš, postihnout jednu areté u všech prrípadů tak jako v ostatních věcech“ (74b) ${ }^{17}$, proto úkolem Sókratovým je provést s Menónem takový nácvik (75a), který by mu na jiném př́ikladu osvětlil, jak postupovat v prrípadě areté. Jelikož Menón se hlásí k Empedokleovi (ve fyzice) a ten byl zase žákem Pýthagorovým ( $v$ matematice), je prŕklad definice podán $z$ této oblasti (a ze stejného důvodu je pravděpodobně $\mathrm{v}$ dalším průběhu dialogu zvolena pro příklad anamnésis, rozpomínání, oblast geometrie).

Zarážející je, co následuje. Menón okamžitě podanou definici tvaru odmítne slovy „toto je pošetilé“. Čtenář se zarazí, přečte si ještě kousek textu, a je zaražen ještě víc argumentem proti podané definici: Co kdyby někdo řekl, že neví, co je barva? „Někdo“ určitě není Menón, a těžko hledat někoho, kdo by vlastně nevěděl, co je barva. Sókratés v argumentu proti podané definici vidí další osvojený sofistický úskok, jak naznačuje slovy o „odbornících v hádání a slovních zápasnících“ (75d). Co je však smyslem Menónova příkrého odmítnutí? Někteří interpreti jsou toho názoru, že námitka není zamířena proti nesrozumitelnosti definice či její přílišné složitosti, ale právě naopak - pro Menóna je vadou nedostatek sofistikovanosti, esoteričnosti či technické vytř́ibenosti. ${ }^{18}$ Stejně jako v jeho předporozumění areté (vposledku uznává hlavně mužskou aretê), i zde můžeme číst jeho nelibost nad tím, že by se měl spokojit s tak banálním postižením něčeho. Na druhou stranu ale nutno podotknout, že sám nestačí na vytř́benější Sókratovu argumentaci, a na mnoha místech dialogu jasně vysvítá jeho neochota nad problematikou hlouběji přemýšlet. ${ }^{19}$ Tohoto nesouladu si interpretka Roslyn Weiss výslovně nevšímá; přikloňme se předběžně $\mathrm{k}$ tomu, že

${ }^{16}$ Novotný zde v rámci snahy terminologicko překladatelsky co nejlépe postihnout význam pojmu areté přidává $\mathrm{k}$ originálnímu "Vždyt' spravedlnost je ctnost/aretée ještě slova "a patři ke zdatnosti“ (73d). To vnímám jako historicky vhodné, v současnosti již spíše matoucí.

17 Bylo by zde na místě upozornit - bez ambice prokazovat, že snad takové stanovisko zastává sám Menón - na Wittgensteinova Filosofická zkoumání, s jejich řeklo by se historickým opuštěním "jednotícího vidu“ jako redukcionistického a zavádějícího; místo něj je tu "„<rodová> podobnost", "chápeme špatně roli, jakou ideál hraje $v$ našem způsobu vyjadřování. ... jsme ideálem oslepeni, a nevidíme tudíž zřetelně skutečný zpưsob používání..." § 100 citovaného díla (vydání Praha 1993, str. 61). Samožrejmě, Wittgenstein to říká po Traktátu, a hlavně po dvou tisících let metafysiky, pro niž jednotící vid byl alfou a omegou.

${ }^{18}$ Weiss, Virtue in the Cave (2001), str.28-29. Menón je přímo označen za <intelektuálního> snoba.

${ }^{19}$ Blíže se problematikou Menóna jako jednoho z mluvčích zabývá Scott (2006) v kapitole 5 v oddílech "Intelectual laziness" a "Coercion", in Plato's Meno, str. 60-65. 
Menón v Sókratově definici postrádá jazykovou vytř́ibenost, nebo - jak se ukazuje v dalším průběhu - postrádá, aby odpověd” "byla vznosná jako verš tragédie“ , nebot' ta "se ti líbí více nežli ona <předchozí>“, říká Sókratés (76e). Co se změnilo, že je Menón tak velmi spokojen? Přistoupil terminus technicus empedokleovské nauky, slovíčko aporroai, výrony. Definice vyslovená s jeho pomocí je „výborná“ (76d), což pro Sókrata není velkou pochvalou: jakpak by se nelíbila, když konvenuje zvyku posluchače? Přitom „výron“ je mnohem méně srozumitelný termín než běžně užívané slovo „barva“. Co kdyby někdo řekl, že neví, co je výron? To Menón neřeší. Sókratés spokojen není, dal by přednost předchozí definici, ale Menón nemá dost času, aby si nechal vysvětlit proč; proč by neměl odejít před zasvěcením - v jeho případě zasvěcením do objevu sféry morálního, něčeho - ač samo silou - nedisponovatelného, řečeno v duchu Patočkových úvah z Kacířských esejü. Uvítal by spíše více takových věcí, které dobře zná, rozhodně by si udělal čas na nějaké nové nuance z oblasti empedokleovské nauky; zdá se, že o ní Sókratés něco ví. Ten však nemá zájem, protože těžiště jeho zájmu leží úplně jinde než v epistemologii barev.

\section{TŘETÍ DEFINICE (77b-79e) - boulesthai a(nebo) epithumein?}

O co Sókratovi jde, je sám lidský život a jeho kvalita (snad soulad s božským údělem, nikoliv však předurčujícím). „Nyní však je lidská areté, ta, o kterou Sókratovi jde, areté naší duše. " 20 Jak asi působí na takovou životní atitudu třetí Menónova definice?

"Areté je, jak praví básník, těšiti se z krásných věcí a míti moc; a já nazývám areté to, toužit po krásných věcech a býti schopen si je opatřovat" (77b)

Přes Sókratovu snahu opět nevidíme u Menóna ani záblesk morálního pochopení smyslu otázky po areté: rozumnost (či uměřenost) a spravedlnost $\mathrm{v}$ Menónových úvahách takříkajíc nejsou vůbec doma. Jediný klad třetí definice je, že už se netřiští v mnohost př́ikladů, ani nedefinuje celek částí; nepoužívá ani pojmy, o nichž by (jako například o barvě) někdo mohl říci, že je nezná. Přetrvává elitářské pojetí areté: ne každý, ale jen ten, kdo je nadán zálibou ve vytříbeném/krásném, a zároveň ten, kdo (to překvapení!) má moc (si to zálibné opatřit). Sókratés se však ze své koncentrace na areté lidského života přístupnou všem (byt’ ne bez úsilí) vyvést nenechá; jeho otázku, zda krásné je totéž co dobré, Menón nevidí jako problematickou. Výrazy agathon, ariston, areté $^{21}$ - pořád jsme přeci u té výjimečnosti, neběžnosti, elity... Menón zůstává vytrvale vězet ve svém světě, natolik nereflektovaně, že nevnímá, jak velký posun takové slovní vyjádření umožní: krása je výjimečná stejně jako touha po ní a moc krásný předmět si opatřit; dobro však je přirozeným cílem, přirozenou touhou všech, problematická je jen ta moc si dobro opatřit. Zásadní rozdíl v pojetí agathon je i konflikt

\footnotetext{
${ }^{20}$ Patočka, Sókratés, str. 127.

${ }^{21}$ Pracovně přeložme jako "to dobré“, ,"to nejlepši” , "to vynikající a výjimečné“.
} 
mezi Sókratovým „všichni touží po dobrých věcech“ (77c) a Menónovým „To se mi nezdá ... někteří touží i po zlých věcech“. Copak ale ti, kteří touží po zlých, ví, že jsou zlé? Ano, i takoví jsou, tvrdí Menón, a tak poslední zbraní, která ho zasáhne, je poukaz na účinek takové touhy: ti, kteří touží po zlých věcech, a ví, že jsou zlé, věří zároveň, že jejich dosažení bude pro ně přínosem, nikoliv škodou. Takoví, kteří touží po zlých věcech, a ví zároveň, že jsou zlé, a ví zároveň ještě navíc, že jim jejich dosažení uškodí, jsou „ubozí" (78a) a nešt'astní, a nikdo si přece nepřeje vědomě být ubohý a nešt'astný - ano, skoro se tak zdá, uzná nakonec Menón, a je tím vyřízena první polovina jeho třetí definice, protože - jak jsme uvedli výše - dobro je přirozeným cílem, přirozenou touhou všech. ${ }^{22}$ Zvítězila Sókratova námitka, že nikdo, kdo věří, že zlé věci mu přinesou prospěch, neví skutečně, že jsou zlé, ale věří bezprostředně, že jsou dobré. Stěžejní pro tuto kritiku první polovinu třetí definice je tak jedno z mála míst, kde je v dialogu výslovně vidět dvojí významová rovina řeči o areté: je to Sókratovo rozlišení mezi toužit po něčem (epithumein) a chtít něco (boulesthai). Menón toto rozlišení vůbec nevidí23 - nakročeno $\mathrm{k}$ němu je ve ztotožnění krásných věcí s dobrými věcmi $(77 \mathrm{~b})$, s klíčovým důsledkem: Sókratés totiž nijak nepopírá, že je možno toužit po zlých věcech, ale nepřipouští vůbec jako možné, aby někdo chtěl zlé - nikdo si přece nepřeje vědomě být ubohý a nešt'astný!

Jak dopadne druhá polovina třetí definice? Moc, síla si něco opatřit, podmanit - o to přeci v Menónově pojetí areté šlo od samého začátku! Jestliže se ukázalo, že odlišnost mezi lidmi, která $\mathrm{z}$ jednoho dělá držitele areté a $\mathrm{z}$ druhého ne, nespočívá $\mathrm{v}$ touze ani chtění, spočívá tedy $\mathrm{v}$ moci: někdo má moci více, někdo méně. Jenže jak vidno, Sókratés si nemůže pomoci, a opět tahá za jinou stranu provazu: „nenazýváš snad dobry <jejichž dosahování je projev moci a tedy areté> ... zdraví a bohatství?" (78c), stejně jako Menón opět tahá za tu "svojí“: jde mu hlavně o to zlato, stříbro, a pocty str.47):

22 Scott (2006) uvádí pro přehlednost myšlenkového postupu následující schéma (Plato's Meno,

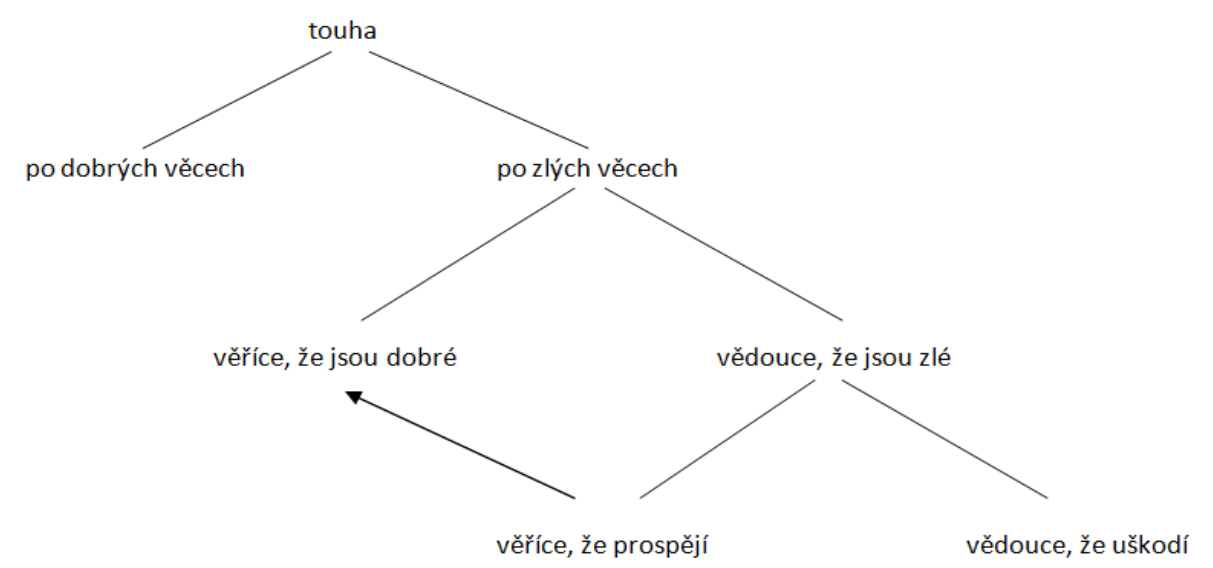

${ }^{23}$ Nikoliv za významový posun, ale pouze za slovní vyjasnění pokládají rozlišení epithumein od boulesthai Brickhouse a Smith, viz blíže Brickhouse, Thomas C.; Smith, Nicholas D. (2010), Socratic Moral Psychology. Cambridge University Press 2010, str. 66. 
v obci a úřady - „myslím vesměs takovéto věci“ (78c). V narážce na perského krále24 se Sókratés výslovně zeptá: to je tedy vše, oč ti, Menóne, jde? „Či ti na tom nic nezáleží, ... když si někdo opatřuje ty věci nespravedlivě, ty je stejně nazýváš areté?" (78d) A to už je příliš připustit i pro Menóna, což zároveň znamená, že síla bez morálního základu není hodna názvu areté, a jsme tam, kde jsme byli. Pro získání areté je totiž možná nutností použití síly, avšak ne prosté, hrubé síly, ale takové, která je doprovázena některou z částí areté - spravedlností, rozumností, zbožností... To je velmi pěkně vidět na prříkladu, který Sókratés „vykouzlí“ vzápětí: někdy je areté nekonat nic, spíše než konat bez oněch částí areté. Nic nemůže být reálně vzdálenější stanovisku Menónovu: lepší slepá, ale silná akce se silným výsledkem, než žádná akce! A ted' musí poslouchat, že snad nečinění je někdy tou pravou areté, zatímco uplatnění síly (bez doprovodu částí areté) je opak areté, je špatností? Pokud by byla relevantní interpretace Patočkova, že si od samého počátku zamýšlí Menón ze Sókrata učinit dobrý den ${ }^{25}$ (to pokládáme za přilišné zjednodušení), pak právě v tuto chvíli se musí Menón cítit tak, že si Sókratés snad dělá dobrý den z něj. Sókratés mu takříkajíc vypálil rybník, na který byl tak pyšný, a není divu, že následuje velmi osobní reakce, kdy označí Sókrata jednak za rejnoka, který působí strnutí všem kolem sebe (udělá z něj $\mathrm{v}$ podstatě mořskou škodnou), a rovněž za kouzelníka, který umí omámit druhé tak, že ti pak neví, jak se jim to vlastní slova v ústech obrátila. A aby to nebylo málo, ještě mu vyhrozí, at' Sókrata snad nenapadne opouštět Athény, kde mu takové počínání trpí, protože jinde by skončil po právu ve vězení!

Další průběh dialogu přes svou bohatost na neméně významná filosofická témata není předmětem této práce; úkolem je tedy jen stručně shrnout dosavadní průběh.

\section{ZÁVĚR}

Viděli jsme, že všechny tři Menónovy definice ilustrují se vzrůstající měrou kriticky nereflektovaný předpoklad jejich autora, že areté se týká vlastně pouze bohatých a mocných mužů. První definice (71e) poskytuje obecné rozumění areté jako prostředku k dosažení společenského a politického úspěchu, a naznačuje, jak velmi je autor definice na straně elitářsky pojatých aretai, spíše než na straně aretai kooperativních. Menónův postoj graduje $\mathrm{v}$ druhé definici (73c), která popisuje areté jako schopnost vládnout ostatním, tedy výslovně se areté takto pojatá týká $\mathrm{v}$ tehdejší společnosti pouze mužů. A třetí definice $(77 \mathrm{~b} n \mathrm{n}$.) redukuje areté na schopnost bohatých a mocných mužů opatřovat si krásné věcí podle libosti. ${ }^{26}$

24 To může být autorská Platónova narážka na pozdější Menónovy skutky ve funkci jednoho z velitelů žoldnéřské armády ve službách krále Kýra, viz k tomu blíže Xenofontovu Anabázi.

25 “Menón jako horlivý napodobovatel Gorgia je asi přesvědčen, že nemůže být rozumně řeči o tom, že by hlavním předmětem sofistické výuky byla tradiční zdatnost, a míní si ze Sókrata udělat dobrý den." , Patočka, Platón, str. 197.

${ }^{26}$ Ionescu, C., Plato's Meno. An Interpretation, Lexington Books 2007, str. 9. 
Zároveň jsme sledovali místy jemně ironický a místy poněkud drsný střet takového životního názoru s pozicí Sókratovou, radikálně odlišnou. Areté, o kterou jde Sókratovi, je zcela jiná areté. Je to areté naší duše. Tomu, kdo prošel morálním nahlédnutím, se areté ukáže jako snaha a úsilí o jednotící cíl lidského života, o to, co je $\mathrm{v}$ životě podstatné, a zároveň jako odmítnutí všeho nahodilého, co život pouze znovu a znovu tříští.

Gadamerovými slovy je „zde ... zpočátku přivedena ke ztroskotání řada pokusů o definici areté, které více či méně jasně odhalují, jak za morální konvencí stojí jen a jen skutečnost touhy po moci. Poslední odpověd', o niž se Menón pokusil, to přímo vyslovuje, když si Menón osvojuje básníkovo slovo chairein te kaloisi kai dynasthai tak, jako by areté neznamenala nic jiného než: krásu, po které člověk touží a kterou je schopen si opatřit (77b). Ale nový krok spočívá v poukazu na to, že ,aporié, v nichž Menónovy pokusy o určení areté končí, představují samu podmínku, bez které není možné se na areté ptát. Ptát se tu však znamená: ptát se sám sebe.“ 27

Tak se nám při četbě dialogu ukázalo, že areté je jistě Sókratovým hlavním tématem, nikoliv však Menónovým. Že sókratovská areté vyžaduje sebeporozumění, a že právě to Sókratovu partnerovi v dialogu chybí; spoléhá se totiž na pevnost toho poznání, které jsme výše označili za tradiční. Vskutku nečekal Gorgiův žák, že pozná někoho, kdo má v sobě takovou sílu, aby se postavil celé tradici!

Podobně i do hloubi položená „otázka, co je areté, by musela vést k vědění Dobra“28 - a to je něco zcela jiného, než čemu svou sílu životní věnuje Menón. Ten jako žák sofistův sice možná zahlédá, že „,svět tradičních norem potřebuje odůvodnění, ale není tohoto odůvodnění schopen“", ale ten nárok, se kterým jako představitel sofistiky, nové paideia, přichází, není toto potřebné odůvodnění, ale „ve skutečnosti techné úspěchu.“" 29 „Sókratova otázka: co je dobré? znamená: co je jediným, obecným, základním cílem lidského života? ... Mluvit o cíli a smyslu života stalo se od <Sókratovy> doby něčím každodenním, samozřejmým, takže již necítíme, co tato otázka vlastně znamená a jaká nesmírná paradoxie i jaký nečekaný nárok je v ní obsažen. Tato otázka ve své původní sókratovské intenzitě znamená: jaký je v životě cíl, který není sám vůči žádnému dalšímu cíli prostředkem? Kde je jednota, které lze podřadit celý život do posledku a bez výjimky? ... Sókratés se nesetkal s nikým, kdo by věděl o Dobru, ba málokdy s někým, kdo vůbec chápe smysl jeho otázky. Nerozumí se jí, poněvadž tomu stojí v cestě ona mnohá dobra, ony bezprostřední, naivní životní cíle, které jsou tu před vší otázkou a působí iluzi, jako by život odjakživa již měl v sobě vztyčen a upevněn svůj poslední cíl.“30

\footnotetext{
27 Gadamer, H.-G., Idea Dobra mezi Platónem a Aristotelem, str. 38-39.

28 Gadamer, H.-G., Idea Dobra mezi Platónem a Aristotelem, str. 41.

${ }^{29}$ Gadamer, H.-G., tamtéž, str. 36.

30 Patočka, J., Věčnost a dějinnost, in: Negationí platonismus, str. 69-70.
} 


\section{Literatura}

Bedu-Addo, J.T. (1984), "Recollection and the Argument 'From a Hypothesis' in Plato's Meno." Journal of Hellenic Studies 104: 1-14. Jeho názor na povahu dialogu ovšem pouze citován z výše uvedené Weiss (2001).

Brickhouse, Thomas C.; Smith, Nicholas D. (2010), Socratic Moral Psychology, Cambridge University Press 2010.

Fine, G. (2007), Enquiry and Discovery. A Discussion of Dominic Scott, Plato's Meno, in: David Sedley (ed.), Oxford Studies in Ancient Philosophy XXXII: Summer 2007.

Gadamer, H.-G. (2010), Idea Dobra mezi Platónem a Aristotelem, Oikoymenh 2010.

Havlíček, A. (ed.) (2000), Platónův dialog Menón (sborník), Oikoymenh 2000.

Ionescu, C. (2007), Plato's Meno. An Interpretation, Lexington Books 2007.

Irwin, T. (2007), The Development of Ethics, Volume I., Oxford University Press 2007.

Knoll, V., Reflexe nad platónskou areté na základě dialogů Prótagoras a Menón. (Bez uvedení roku na $<\underline{\text { http: / tyras.sweb.cz/doct/arete.htm }>\text { ) }}$

Patočka, J. (1990), Věčnost a dějinnost, in: Negationí platonismus, Československý spisovatel 1990.

Patočka, J. (1991), Sókratés, Státní pedagogické nakladatelství 1991.

Patočka, J. (1992), Platón, Státní pedagogické nakladatelství 1992.

Patočka, J. (1999), Platón a Evropa, Evropa a doba poevropská, obě in: Péče o duši II., Oikoymenh 1999.

Platón (2000), Menón, in: Euthydémos, Menón, Oikoymenh 2000.

Scott, D. (2006), Plato's Meno, Cambridge University Press 2006.

Weiss, R. (2001), Virtue in the Cave. Moral Inquiry in Plato's Meno, Oxford University Press 2001.

Xenofón, Anabaze, Odeon 1974. 


\section{E-LOGOS}

ELECTRONIC JOURNAL FOR PHILOSOPHY

Ročník/Year: 2014 (vychází průběžně/ published continuously)

Místo vydání/Place of edition: Praha

ISSN 1211-0442

Vydává/Publisher:

Vysoká škola ekonomická v Praze / University of Economics, Prague

nám. W. Churchilla 4

Czech Republic

13067 Praha 3

IČ: 61384399

Web: http://e-logos.vse.cz

Redakce a technické informace/Editorial staff and technical information:

Miroslav Vacura

vacuram@vse.cz

Redakční rada/Board of editors:

Ladislav Benyovszky (FHS UK Praha, Czech Republic)

Ivan Blecha (FF UP Olomouc, Czech Republic)

Martin Hemelík (VŠP Jihlava, Czech Republic)

Angelo Marocco (Pontifical Athenaeum Regina Apostolorum, Rome, Italy)

Jozef Kelemen (FPF SU Opava, Czech Republic)

Daniel Kroupa (ZU Plzeň, Czech Republic)

Vladimír Kvasnička (FIIT STU Bratislava, Slovak Republic)

Jaroslav Novotný (FHS UK Praha, Czech Republic)

Jakub Novotný (VŠP Jihlava, Czech Republic)

Ján Pavlík (editor-in-chief) (VŠE Praha, Czech Republic)

Karel Pstružina (VŠE Praha, Czech Republic)

Miroslav Vacura (executive editor) (VŠE Praha, Czech Republic) 